Volume 4, Number 2, 2018

\title{
Improvement of 6/10 kV Distribution Power Networks Efficiency
}

\author{
Zinoviy Bakhor, Andriy Kozovyi, Heorhiy Lysiak, Andriy Yatseiko* \\ Lviv Polytechnic National University, 12 S. Bandera St., Lviv, 79013, Ukraine
}

Received: June 08, 2018. Revised: October 12, 2018. Accepted: November 07, 2018.

(C) 2018 The Authors. Published by Lviv Polytechnic National University.

\begin{abstract}
The study focuses on the ways to improve the operation efficiency of $6 \mathrm{kV}$ and $10 \mathrm{kV}$ distribution power networks on the example of the Horodok District Power Network, Lvivoblenergo PJSC (Ukraine). The main drawbacks of these power networks are the poor condition of the electrical equipment and great length and insufficient transmission capacity of the existing $6 / 10 \mathrm{kV}$ power transmission lines. One of the most serious problems is the fact that the power networks are not prepared for an efficient operation, taking into account the predicted power consumption increase in this area in the near future. The study used a multifactor model, which enabled taking into consideration the power consumption tendencies in the area, industrial growth rate, personal income growth rate and implementation of energy efficiency measures. A computer simulation of steady-state operation modes for probable ways of power networks' development, including their changeover to $20 \mathrm{kV}$, was applied. A quantitative characteristic of the technological indices for a set of typical modes was obtained, which made it possible to establish a comparative efficiency of changing over to $20 \mathrm{kV}$ in relation to other options. This is due to the fact that such a change offers a number of specific advantages in terms of the structure and operation efficiency of the distribution power networks, for instance, an increased transmission capacity of the power lines and improved conditions of the normalization of the electrical power quality indices for the consumers.
\end{abstract}

Keywords: distribution power network; steady-state mode; voltage level; active power loss; transmission capacity.

\section{Introduction}

The distribution power networks (PN) and most rural PN in Ukraine feature a great length of power lines (PL) and their relatively low capacity. The contemporary state of the distribution and supply PN is characterized by a large percentage of worn-out and obsolete electrical equipment being in use, electric circuits in need of optimization and their poorly automatized elements. This causes big losses of electrical power (up to $15 \%$ ) in PN, poor electric reliability, large expenses on emergency repairs and compromised electrical safety for households first and foremost. The listed disadvantages of such 10 (6) kV PN affect the System Average Interruption Duration Index (SAIDI) and System Average Interruption Frequency Index (SAIFI) used for power supply reliability rating.

Therefore, the 10 (6) $\mathrm{kV}$ distribution PN in their present-day condition are conceptually unsuitable for an efficient operation and for fulfilling the requirements of a reliable quality of power supply to consumers and, most importantly, they do not deliver the desired profits. Against this background, it is necessary to decide upon the selection of the optimal options for PN development, including their redesign and upgrade.

The study of possible ways of raising the $10(6) \mathrm{kV}$ distribution power networks operation efficiency and comparative analysis of their efficiency are, therefore, of topical importance.

\footnotetext{
" Corresponding author. Email address: yats80@ukr.net
}

This paper should be cited as: Z. Bakhor, A. Kozovyi, H. Lysiak, A. Yatseiko. Improvement of 6/10 kV distribution power networks efficiency. Energy Eng. Control Syst., 2018, Vol. 4, No. 2, pp. 65 - 72. https://doi.org/10.23939/jeecs2018.02.065 


\section{The research object}

The 10/6 kV distribution PN of the Horodok District Power Network (DPN), Lvivoblenergo PJSC (Ukraine) were selected as the object of the research. This object features a great length of PL and poor technical condition of the major electrical equipment; besides, it is necessary to take into account the predicted growth rate of electricity consumption in this area.

According to Lvivoblenergo, only 163 transformer substations (TS) out of 308 (the subscriber TS were not taken into account) are in a good condition (52.92\%), 94 TS are in need of major repair (30.52\%), 50 TS need redesigning $(16.23 \%)$ and one TS qualifies for a complete replacement ( $0.33 \%)$ (Fig. 1).

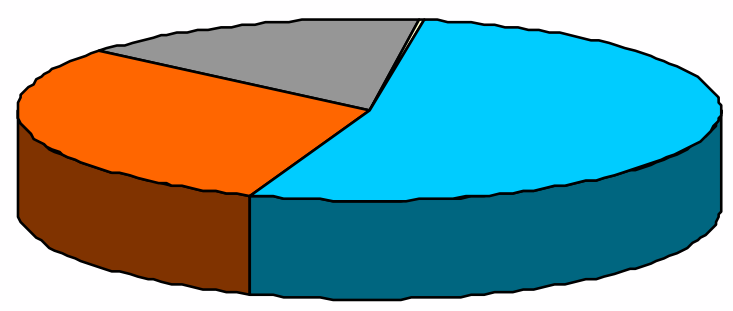

$\square 30.5 \%$ in a good technical condition

$16.2 \%$ need major repair

$\square 0.3 \%$ need redesigning

$52.9 \%$ need replacement

Fig. 1. Technical condition of 10(6)/0.4 kV transformer substations in Horodok DPN.

The percentage of the worn-out electrical equipment of TS that is run far beyond its service life (1.5-2-fold service duration) is increasing annually and has already exceeded $90 \%$. The technical condition of the $10(6) / 0.4 \mathrm{kV}$ distribution PN elements is presented in Table 1 based on the data provided by Lvivoblenergo PJSC as of January 01, 2016.

Table 1. Technical condition of $10(6) / 0.4 \mathrm{kV}$ distribution power networks of Horodok DPN.

\begin{tabular}{|l|c|c|c|c|c|}
\hline \multirow{2}{*}{$\begin{array}{c}10(6) / 0.4 \mathrm{kV} \text { PN } \\
\text { elements }\end{array}$} & \multirow{2}{*}{$\begin{array}{c}\text { Length, km or } \\
\text { number, items. }\end{array}$} & good & Major repair & Redesigning & $\begin{array}{c}\text { Complete replacement } \\
\text { (unsuitable for further } \\
\text { operation) }\end{array}$ \\
\cline { 4 - 6 } & & & & & - \\
\hline OL 10(6) & 507.9 & 37 & 63 & - & - \\
\hline CL 10(6) & 1.70 & 100 & - & - & - \\
\hline OL 0.4 & 869.849 & 13.8 & 81.8 & - & - \\
\hline CL 0.4 & 1.120 & 100 & - & - & 0.3 \\
\hline TS-10(6)/0.4 & $308^{*}$ & 52.92 & 30.52 & 16.23 & 0.33 \\
\hline
\end{tabular}

Note: * without subscriber TS-10(6)/0.4 kV.

Therefore, due to a lengthy service life, most of the existing objects of the Horodok DPN distribution PN do not conform to the requirements stated in The Technical Policy of Construction and Operation of Distribution Power Networks, Part 2 СОБУ МЕВ EE 40.1-00100227-01:2016.

\section{Research aim and objectives}

The study aims at searching for possible ways to improve the efficiency of the existing distribution PN of Horodok DPN, taking into account a prospective increase in the load in this area.

The aim of the research is to be fulfilled through pursuing the following objectives:

1) exploration of the existing solutions for improving the distribution power network efficiency;

2) analysis of the structure and parameters of the existing power networks of Horodok DPN, taking on board the predicted significant growth of electricity consumption in the area.

3) computer simulation of the steady-state modes for possible ways of the power networks development under consideration and comparative analysis of the technological indicators regarding the estimation of the efficiency of changing over to $20 \mathrm{kV}$ as compared to other options. 


\section{Analysis of the recent studies and publications}

The efficiency of the distribution PN is evaluated according to such criteria as technical energy losses (TEL), transmission capacity of the power lines and transformers, voltage level on the TS buses, power network reliability indices SAIDI and SAIFI. The technical measures used to improve the efficiency include raising the diameter of PL wires and cables, change over to a higher voltage level, installation of compensating devices (CD), embedding distributed generation (DG) devices, power network sectionalisation and reconfiguration. These measures, when properly implemented, ensure optimal TEL and normalized voltage levels on the substation buses. Increased diameter of PL wires and cables and changing over to a higher voltage level are applied for networks that have reached the maximum of its transmission capacity.

TEL minimization in distribution PN is a matter of great interest for researchers [1]. The measures most often used, according to [1], are the optimal location of CD in the power network, network reconfiguration and embedding DG. For instance, in $[2,3]$ the authors discuss the issues of optimal selection of the capacitor banks' location in distribution power networks in order to minimize TEL and improve the voltage level. The use of DG is an alternative to this. According to [4, 5], optimal DG location in the network, based on the proposed methods, ensures minimum TEL. The authors in [6, 7] showed that the reconfiguration of the distribution PN using the developed methods also works towards TEL minimization and ensures the necessary level of the voltage in the network. Besides, as it is noted in [8], sectionalisation of $6 / 10 \mathrm{kV}$ distribution power networks with automatic breakers results in the improved integral reliability indices.

The methodology for the evaluation of technical measures aimed at reducing TEL is presented in [9]. The authors proposed a value of the current for which an increase in the diameter of PL wires and cables in the network becomes economically viable and the criterion for switching the power network to a higher voltage level. A changeover of the distribution power networks to the voltage $20 \mathrm{kV}$ is an effective way to improve their efficiency, which was verified by the research outcomes presented in $[10,11,12]$.

Therefore, the analysis of the research publications shows that improving the efficiency of the distribution PN is an important issue. For each network, depending on its configuration, lines' length and load, development prospects and embedding of DG, an optimal technical measure can be selected, which would ensure high criteria of its operation. This requires the study of the network operation modes with the development prospects taken into consideration.

\section{Presentation of the main material}

The distribution PN of Horodok DPN are powered from nine TS of 110/35 kV PL, Lvivoblenergo PJSC: Horodok-146 (35/10 kV), Horodok-108 (35/6 kV), Halychany $(35 / 10 \mathrm{kV})$, Zapanska $(35 / 10 \mathrm{kV})$, V. Liubin-T $(110 / 35 / 10 \mathrm{kV})$, V. Liubin $(35 / 6 \mathrm{kV})$, Komarno $(110 / 35 / 6 \mathrm{kV})$, Rudky-T (110/35/10 kV) and Horozhanka (35/10 kV).

PN $(10 / 6 \mathrm{kV})$ of Horodok DPN include 33 power supply feeders $10(6) \mathrm{kV}$, the total length of the power lines of which is $510.72 \mathrm{~km}$, and $448 \mathrm{TS} 10(6) / 0.4 \mathrm{kV}$ with the total installed capacity of the transformers of 90.495 MVA.

The information on the structure and parameters of PN being studied is summarized in Table 2.

The study was conducted on the basis of simulating the typical steady-state operation modes for winter PN load peaks for the following variants of its development:

Variant 1. The existing $10(6) \mathrm{kV}$ PN with base-load demand.

Variant 2. $10 \mathrm{kV}$ PN with base-load demand after switching $6 \mathrm{kV}$ feeders of the existing PN to $10 \mathrm{kV}$.

Variant 3. $20 \mathrm{kV}$ PN with base-load demand after switching the existing 10(6) kV PN to $20 \mathrm{kV}$.

Variant 4. $20 \mathrm{kV}$ PN after switching the existing $10(6) \mathrm{kV}$ PN to $20 \mathrm{kV}$, taking into account the predicted increase in the load for the next 15 years.

The base-load demand of $10(6) / 0.4 \mathrm{kV}$ TS and winter peaks were generally evaluated for the existing $10 / 6 \mathrm{kV}$ PN based on the performance measurements made in December, 2016, taking into account the technical specification for connecting new consumers to the power networks. The loads of the subscriber TS were calculated taking into consideration their installed capacity and respective demand factors. The demand factors were estimated from the condition of the steady-state mode balancing in accordance with the performance measurements data.

The forecast for growth of the distribution PN load for further 15 years was made using a multifactor model of electrical power consumption that takes into account the power consumption tendencies in the area, industrial growth rate, personal income growth rate and implementation of energy efficiency measures [12]. 
Table 2. Structure and parameters of $10 / 6 \mathrm{kV}$ distribution power network of Horodok DPN.

\begin{tabular}{|c|c|c|c|c|c|}
\hline \multirow{2}{*}{$\begin{array}{c}\text { Transformer substation } \\
110 / 35 \mathrm{kV} \text { PN }\end{array}$} & \multirow{2}{*}{ Feeder } & \multirow{2}{*}{$\begin{array}{c}\text { Rated } \\
\text { voltage, } \mathrm{kV}\end{array}$} & \multirow{2}{*}{ PL length, km } & \multicolumn{2}{|c|}{ TS $10(6) / 0.4 \mathrm{kV}$} \\
\hline & & & & Number & $\begin{array}{c}\text { Installed capacity, } \\
\text { MVA }\end{array}$ \\
\hline \multirow{4}{*}{ Horodok-108 (35/6 kV) } & $108-01$ & 6 & 14.96 & 25 & 8.36 \\
\hline & $108-02$ & 6 & 34.99 & 39 & 7.9 \\
\hline & $108-03$ & 6 & 0.9 & 2 & 0.32 \\
\hline & $108-04$ & 6 & 0.8 & 3 & 0.82 \\
\hline \multirow{4}{*}{ Horodok-146 (35/10 kV) } & $146-01$ & 10 & 0.16 & 1 & 0.25 \\
\hline & $146-11$ & 10 & 41.12 & 41 & 10.6 \\
\hline & $146-13$ & 10 & 47.9 & 32 & 7.1 \\
\hline & $146-18$ & 10 & 5.5 & 8 & 1.17 \\
\hline \multirow{4}{*}{ V. Liubin $(35 / 6$ kV) } & $161-08$ & 6 & 29.1 & 29 & 3.86 \\
\hline & $161-10$ & 6 & 19.23 & 16 & 2.65 \\
\hline & $161-11$ & 6 & 11.7 & 15 & 2.93 \\
\hline & $161-12$ & 6 & 0.7 & 2 & 0.35 \\
\hline \multirow{8}{*}{ Halychany $(35 / 10$ kV) } & $162-22$ & 10 & 5.18 & 3 & 1.66 \\
\hline & $162-23$ & 10 & 0.19 & 1 & 1 \\
\hline & $162-24$ & 10 & 0.15 & 1 & 1 \\
\hline & $162-25$ & 10 & 21.33 & 20 & 3.99 \\
\hline & $162-26$ & 10 & 13.23 & 13 & 1.48 \\
\hline & $162-27$ & 10 & 5.18 & 3 & 1.66 \\
\hline & $162-28$ & 10 & 30.3 & 18 & 2.515 \\
\hline & $162-29$ & 10 & 13.23 & 17 & 5.11 \\
\hline \multirow{4}{*}{ Zapanska (35/10 kV) } & $127-30$ & 10 & 11.14 & 10 & 2.52 \\
\hline & $127-31$ & 10 & 19.21 & 12 & 2.03 \\
\hline & $127-33$ & 10 & 7.96 & 9 & 1.74 \\
\hline & $127-34$ & 10 & 34.56 & 16 & 3.43 \\
\hline \multirow{5}{*}{ Komarno $(110 / 35 / 6 \mathrm{kV})$} & $165-05$ & 6 & 35.23 & 20 & 2.77 \\
\hline & $165-06$ & 6 & 20.77 & 20 & 3.06 \\
\hline & $165-07$ & 6 & 23.56 & 24 & 4.0 \\
\hline & $165-14$ & 6 & 0.15 & 1 & 0.18 \\
\hline & $165-19$ & 6 & 29.44 & 22 & 2.93 \\
\hline Rudky-T (110/35/10 kV) & $43-09$ & 10 & 20.82 & 15 & 1.88 \\
\hline \multirow{2}{*}{ V. Liubin-T $(110 / 35 / 10 \mathrm{kV})$} & T-20-14 & 10 & 8.33 & 8 & 0.97 \\
\hline & T-20-15 & 10 & 2.69 & 1 & 0.16 \\
\hline Horozhanka $(35 / 10 \mathrm{kV})$ & $58-02-21$ & 10 & 1.01 & 1 & 0.1 \\
\hline
\end{tabular}

The simulation of PN under consideration, computation of the coordinates of the typical steady-state modes and their analysis were performed with the software package Analysis of Power Networks Operation Modes (APNOM) $(« \mathrm{APEM}))[13]$.

The low-voltage buses of the respective transformer substations (110/35 kV PN, Horodok DPN) were taken as the balancing nodes for the nodalization diagram of the variants.

The loss of voltage on the way to the most remote TS $10(6) / 0.4 \mathrm{kV}$ and voltage deviation on its buses expressed as percentage were determined with reference to the set-point voltages of the balancing nodes and rated voltages of PN, respectively.

The voltage values in the balancing nodes $(U b)$ were assumed in accordance with the data of the performance measurements made in December, 2016.

Variant 1. The existing $10 / 6 \mathrm{kV}$ PN with base-load demand. The analysis of the operation mode indicators presented in Table 3 shows that some feeders are overloaded and the voltage level on the buses of the remote TS is significantly lower. For instance, the feeder $108-01$ is $41.8 \%$ overloaded; the feeders $108-02$ and $161-08$ are $12.1 \%$ and $60.7 \%$ overloaded, respectively; the feeders $165-05$ and $161-10$ are more than $70 \%$ overloaded.

Poor indicators of electrical power quality according to the voltage criterion are also observed on TS of the relatively non-overloaded feeders. For example, on the TS of the feeder $146-13$, the voltage deviation is $20 \%$ for the load on the main segment of $64.9 \%$. This is due to the fact that this feeder is fairly long $(47.9 \mathrm{~km})$. The similar situation is with TS of the feeders 146-11, 165-05, 127-34 and 165-19, the length of which is within the range from 29.44 to $41.12 \mathrm{~km}$ and the voltage loss varies from 6.7 to $23.2 \%$. 
Table 3. Operation mode indicators of the existing $10(6) \mathrm{kV}$ power network .

\begin{tabular}{|c|c|c|c|c|c|}
\hline \multirow{2}{*}{ Feeder } & \multirow{2}{*}{$\mathrm{Ub}, \mathrm{kV}$} & \multirow{2}{*}{$\begin{array}{l}\text { Load on the } \\
\text { main segment, } \\
\text { A } / \%\end{array}$} & \multicolumn{2}{|c|}{ The most remote TS } & \multirow{2}{*}{ Total losses, $\mathrm{kW}$} \\
\hline & & & Voltage, $\mathrm{kV}$ & $\begin{array}{c}\text { Voltage loss, } \\
\mathrm{kV} / \%\end{array}$ & \\
\hline $108-01$ & 6.2 & $269.5 / 141.8$ & 5.31 & $0.89 / 14.3$ & 307 \\
\hline $108-02$ & 6.2 & $241.1 / 112.1$ & 5.25 & $0.95 / 15.3$ & 296 \\
\hline $108-03$ & 6.2 & $20.19 / 10.6$ & 6.19 & $0 / 0$ & 3 \\
\hline $108-04$ & 6.2 & $19.12 / 10.1$ & 6.19 & $0 / 0$ & 4 \\
\hline $146-01$ & 11 & $6.69 / 3.8$ & 11 & $0 / 0$ & 2 \\
\hline $146-11$ & 11 & $124.16 / 59.1$ & 9.02 & $1.98 / 18$ & 341 \\
\hline $146-13$ & 11 & $136.25 / 64.9$ & 7.98 & $2.92 / 26.8$ & 544 \\
\hline $146-18$ & 11 & $20.26 / 11.6$ & 10.82 & $0.08 / 0.7$ & 10 \\
\hline $161-08$ & 6.2 & $305.25 / 160.7$ & 4.0 & $2.2 / 35.5$ & 868 \\
\hline $161-10$ & 6.2 & $158.7 / 83.5$ & 5.12 & $1.08 / 17.4$ & 251 \\
\hline $161-11$ & 6.2 & $77.55 / 40.8$ & 5.99 & $0.21 / 3.4$ & 35 \\
\hline $161-12$ & 6.2 & $13.56 / 7.1$ & 6.2 & $0 / 0$ & 2 \\
\hline $162-22$ & 10.4 & $18.46 / 8.8$ & 10.34 & $0.06 / 0.6$ & 6 \\
\hline $162-23$ & 10.4 & $16.32 / 8.0$ & 10.4 & $0 / 0$ & 3 \\
\hline $162-24$ & 10.4 & $13.07 / 6.4$ & 10.4 & $0 / 0$ & 3 \\
\hline $162-25$ & 10.4 & $63.1 / 30$ & 9.86 & $0.54 / 5.2$ & 61 \\
\hline $162-26$ & 10.4 & $39.63 / 18.9$ & 10.23 & $0.17 / 1.6$ & 19 \\
\hline $162-27$ & 10.4 & $6.34 / 3.0$ & 10.4 & $0 / 0$ & 2 \\
\hline $162-28$ & 10.4 & $49.05 / 23.4$ & 9.98 & $0.42 / 4.0$ & 48 \\
\hline $162-29$ & 10.27 & $63.43 / 30.2$ & 10.14 & $0.13 / 1.2$ & 4 \\
\hline $127-30$ & 10.4 & $30.63 / 14.6$ & 10.19 & $0.26 / 2.5$ & 17 \\
\hline $127-31$ & 10.4 & $35.94 / 17.1$ & 10.21 & $0.19 / 1,8$ & 24 \\
\hline $127-33$ & 10.4 & $48.24 / 33.0$ & 10.04 & $0.36 / 3.4$ & 38 \\
\hline $127-34$ & 10.4 & $51.11 / 24.3$ & 9.7 & $0.7 / 6.7$ & 61 \\
\hline $165-05$ & 6.5 & $146.85 / 77.3$ & 4.99 & $1.51 / 23.2$ & 263 \\
\hline $165-06$ & 6.5 & $169.92 / 64.1$ & 5.57 & $0.93 / 14.3$ & 192 \\
\hline $165-07$ & 6.5 & $105.07 / 60.0$ & 5.75 & $0.75 / 11.5$ & 126 \\
\hline $165-14$ & 6.5 & $3.68 / 1.6$ & 6.5 & $0 / 0$ & 1 \\
\hline $165-19$ & 6.5 & $111.78 / 58.8$ & 5.18 & $1.32 / 20.3$ & 186 \\
\hline 43-09 & 10.4 & $42.12 / 20.1$ & 10.07 & $0.33 / 3.2$ & 26 \\
\hline T-20-14 & 10.4 & $23.0 / 13.9$ & 10.30 & $0.1 / 1.0$ & 9 \\
\hline T-20-15 & 10.4 & $4.73 / 2.9$ & 10.38 & $0.02 / 0.2$ & 1 \\
\hline 58-02-21 & 10.4 & $3.26 / 1.9$ & 10.4 & $0 / 0$ & 1 \\
\hline
\end{tabular}

The 10/0.4 kV transformers КТП-224, КТП-152, КТП-80, КТП-67, КТП-90 and 6/0.4 kV transformers КТП150, КТП-64, КТП-261, КТП-121, КТП-135, КТП-268, КТП-258, КТП-127, КТП-275, КТП-276, КТП-281 are practically $100 \%$ loaded. Besides, the power transformer TMH-4000/35/6 at V. Liubin substation, when run at full capacity, is $38 \%$ overloaded. The fact that the power lines are very long (the length of the twenty main lines exceeds $20 \mathrm{~km}$; some of them are over $40 \mathrm{~km}$ long) and overloaded causes significant voltage losses in them. Voltage deviation on the high-voltage (HV) buses of some of the remote TS exceeds 10\%, and on the feeder 161-08 it reaches as much as $33.3 \%$.

The total losses of the active power in the power network are 3.7993 MW (of which 3.5379 MW is intermittent losses and 0.2614 MW is relatively constant losses). The obtained results also suggest that the active power losses in the $6 \mathrm{kV}$ power network are twice as large as the losses in $10 \mathrm{kV}$ power network (Fig. 2).

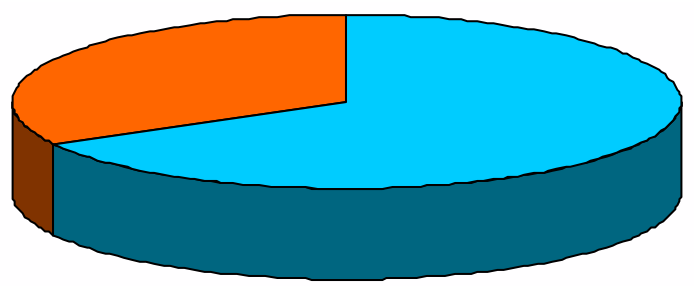

$\square 2.543 \mathrm{MW}$ in $6.0 \mathrm{kV}$ power network

$\square 1.256 \mathrm{MW}$ in $10.0 \mathrm{kV}$ power network

Fig. 2. Structure of active power losses in $10 / 6 \mathrm{kV}$ power network of Horodok DPN. 
Variant 2. $10 \mathrm{kV}$ PN with base load demand after switching $6 \mathrm{kV}$ feeders of the existing PN to $10 \mathrm{kV}$. The changeover of the feeders powered by TS Horodok-108, V.Liubin and Komarno from $6 \mathrm{kV}$ to $10 \mathrm{kV}$ solves the overloading problem (Table 4). Voltage losses in the lines to the remote TS do not exceed $10 \%$ and the voltage deviation on the HV buses of the remote TS are below $4.5 \%$ (feeder 161-08).

Table 4. Operation mode indicators of the existing $6 \mathrm{kV}$ power network after its changeover to $10 \mathrm{kV}$.

\begin{tabular}{|c|c|c|c|c|}
\hline Feeder & $\begin{array}{c}\text { Load on the main segment, } \\
\mathrm{A} / \%\end{array}$ & $\begin{array}{c}\text { Voltage on the most } \\
\text { remote TS, } \mathrm{kV}\end{array}$ & $\begin{array}{c}\text { Voltage losses, } \\
\mathrm{kV} / \%\end{array}$ & Total losses, $\mathrm{kW}$ \\
\hline $108-01$ & $148.58 / 90.1$ & 10.01 & $0.49 / 4.66$ & 132 \\
\hline $108-02$ & $131.88 / 62.8$ & 9.99 & $0.51 / 4.85$ & 118 \\
\hline $108-03$ & $11.88 / 7.2$ & 10.49 & $0 / 0$ & 4 \\
\hline $108-04$ & $11.55 / 7.0$ & 10.5 & $0 / 0$ & 1 \\
\hline $161-08$ & $137.06 / 83.1$ & 9.56 & $0.94 / 8.9$ & 186 \\
\hline $161-10$ & $83.5 / 5.6$ & 9.92 & $0.58 / 5.52$ & 84 \\
\hline $161-11$ & $46.19 / 28.0$ & 10.38 & $0.12 / 1.14$ & 27 \\
\hline $161-12$ & $8.01 / 4.9$ & 10.5 & $0 / 0$ & 2 \\
\hline $165-05$ & $80.4 / 48.7$ & 9.74 & $0.76 / 7.2$ & 97 \\
\hline $165-06$ & $98.18 / 37.0$ & 9.98 & $0.52 / 4.95$ & 98 \\
\hline $165-07$ & $63.01 / 30.0$ & 10.08 & $0.42 / 4.0$ & 64 \\
\hline $165-14$ & $2.28 / 1.1$ & 10.5 & $0 / 0$ & 1 \\
\hline $165-19$ & $61.92 / 37.5$ & 9.8 & $0.7 / 6.7$ & 69 \\
\hline
\end{tabular}

The total losses of active power in the network switched to $10 \mathrm{kV}$ are $2.1475 \mathrm{MW}$, which is by $1.652 \mathrm{MW}$ $(56.52 \%)$ less that for the existing network $6 \mathrm{kV}$ and $10 \mathrm{kV}$.

Switching of the electrical power network of Horodok DPN to $10 \mathrm{kV}$ offers advantages both in terms of lines overloading reduction and ensuring the required voltage level on the TS buses and with respect to decreasing the active power losses in the network. At that, the problems of the $10 \mathrm{kV}$ network operation that was discussed above and that of TS transformers' loading are not solved.

Variant 3. $20 \mathrm{kV}$ PN with base-load demand after switching the existing 10(6) kV PN to $20 \mathrm{kV}$. The operation mode of $20 \mathrm{kV}$ power network of Horodok DPN was computed for the existing configuration and implementation of the overhead power lines with the protection by the wires CIП-3 [14] and with cable lines and intermediate cable done using PE-isolated cables. The TS was equipped with transformers from Ukrainian manufacturers, which have lower idling losses.

The analysis of the obtained results summarized in Table 5 shows a significant reduction of the ampere load of the lines, and the voltage loss on the way to the majority of the remote TS has been brought down to a value not exceeding $3 \%$. At that, the voltage loss on the way to the most remote TS of the feeders $146-11$ and $146-13$ are $5.1 \%$ and $6.4 \%$ respectively, which is also allowable.

The active power losses in $20 \mathrm{kV}$ PN (variant 3) are $0.7797 \mathrm{MW}$, which is by $3.0196 \mathrm{MW}(79.5 \%)$ less that the active power losses in the existing 10(6) kV PN (variant 1) and by $13678 \mathrm{MW}(63.7 \%)$ less than in $10 \mathrm{kV}$ PN (variant 2).

Variant 4. $20 \mathrm{kV}$ PN after switching the existing 10(6) kV PN to $20 \mathrm{kV}$, taking into account the predicted increase in the load for the next 15 years. For the functioning 10(6) kV PN, the operation mode with the predicted load cannot practically exist due to the significant overloading of the main segments of the power lines, large voltage losses in the lines to the remote TS and prohibitively low voltage level on its buses.

The analysis of the computation results for the $20 \mathrm{kV}$ PN mode is indicative of the normalization of the voltage level on the TS buses, as the voltage losses in the lines to the most remote TS do not exceed $3 \%$. Technical active power losses in $20 \mathrm{kV}$ PN amount to $1.237 \mathrm{MW}$, i.e. $2.78 \%$ of the power fed into PN.

\section{Analysis of the results}

The changeover of the power network under study to the voltage $20 \mathrm{kV}$, even if the growth of the load demand for further 15 years is within the forecast range, results in a considerable improvement both in terms of the active power losses and with respect to the voltage level on the consumers buses. The $20 \mathrm{kV}$ network has a fairly large transmission capacity reserve. 
Table 5. Operation mode indicators of the power network being studied after its switching to $20 \mathrm{kV}$.

\begin{tabular}{|l|l|l|c|c|}
\hline Feeder & $\begin{array}{c}\text { Load on the main } \\
\text { segment, } \mathrm{A} / \%\end{array}$ & $\begin{array}{c}\text { Voltage on the most } \\
\text { remote TS, } \mathrm{kV}\end{array}$ & $\begin{array}{c}\text { Voltage } \\
\text { losses, } \mathrm{kV} / \%\end{array}$ & $\begin{array}{c}\text { Total } \\
\text { losses, } \mathrm{kW}\end{array}$ \\
\hline $108-01$ & $73.71 / 30.1$ & 20.74 & $0.26 / 1.2$ & 56 \\
\hline $108-02$ & $65.46 / 26.7$ & 20.71 & $0.29 / 1.38$ & 54 \\
\hline $108-03$ & $5.97 / 5.2$ & 21.0 & $0 / 0$ & 3 \\
\hline $108-04$ & $5.48 / 4.8$ & 21.0 & $0 / 0$ & 3 \\
\hline $146-01$ & $3.49 / 3.9$ & 21.0 & $1.07 / 5.1$ & 1 \\
\hline $146-11$ & $60.39 / 24.6$ & 19.93 & $1.34 / 6.4$ & 132 \\
\hline $146-13$ & $59.78 / 19.3$ & 19.66 & $0.04 / 0.2$ & 7 \\
\hline $146-18$ & $10.39 / 4.2$ & 20.96 & $0.62 / 2.95$ & 66 \\
\hline $161-08$ & $64.94 / 56.5$ & 20.58 & $0.29 / 1.38$ & 35 \\
\hline $161-10$ & $40.25 / 35.0$ & 20.71 & $0.06 / 0.3$ & 15 \\
\hline $161-11$ & $22.15 / 19.3$ & 20.94 & $0 / 0$ & 2 \\
\hline $161-12$ & $4.0 / 3.5$ & 21.0 & $0.03 / 0.14$ & 4 \\
\hline $162-22$ & $8.98 / 3.7$ & 20.97 & $0.27 / 1.28$ & 25 \\
\hline $162-25$ & $30,09 / 12.3$ & 20.73 & $0.09 / 0.4$ & 12 \\
\hline $162-26$ & $19.48 / 8.0$ & 20.91 & $0.03 / 0.14$ & 1 \\
\hline $162-27$ & $3.05 / 1.2$ & 20.97 & $0.22 / 1.05$ & 20 \\
\hline $162-28$ & $23.4 / 9.6$ & 20.78 & $0.14 / 0.66$ & 20 \\
\hline $162-29$ & $30.66 / 12.5$ & 20.86 & $0.11 / 0.5$ & 9 \\
\hline $127-30$ & $14.81 / 6.0$ & 20.89 & $0.1 / 0.5$ & 11 \\
\hline $127-31$ & $17.32 / 7.1$ & 20.9 & $0.19 / 0.9$ & 18 \\
\hline $127-33$ & $32.32 / 9.5$ & 20.81 & $0.46 / 2.19$ & 24 \\
\hline $127-34$ & $24.1 / 9.8$ & 20.64 & $0.38 / 1.8$ & 36 \\
\hline $165-05$ & $38.0 / 33.0$ & 20.62 & $0.26 / 1.24$ & 35 \\
\hline $165-06$ & $47.02 / 19.2$ & 20.74 & $0.21 / 1.0$ & 25 \\
\hline $165-07$ & $29.16 / 11.9$ & 20.79 & $0.35 / 1.67$ & 29 \\
\hline $165-19$ & $29.37 / 25.5$ & 20.65 & $0.16 / 0.76$ & 14 \\
\hline $43-09$ & $20.5 / 8.4$ & 20.84 & & \\
\hline & & & & \\
\hline
\end{tabular}

The analysis of the computation results of the maximum steady-state operation mode of $6 \mathrm{kV}$ and $10 \mathrm{kV}$ power network suggests the overloading of some feeders and a significant drop in the voltage level on the consumers buses. At this stage, this seriously complicates the operation of the power network and causes an excessive increase in the active power loss. Switching the whole power network to $10 \mathrm{kV}$ results in a significant reduction of the voltage level on the buses of the some feeders' consumers, due to which the $10 \mathrm{kV}$ network needs reconfiguration.

Further increase in the load will cause a significant deterioration of the electrical power quality and increase in the technical energy losses and will create a need for a drastic change of the network configuration and changeover to $20 \mathrm{kV}$.

The changeover of the distribution PN to the voltage $20 \mathrm{kV}$ requires a feasibility study and research of the operation modes of the network taking into account the use of distributed generation. The lack of investment funds in the power supplying companies hinders the effective implementation of the measures aimed at improving the performance indicators of the distribution power networks.

\section{Conclusion}

1. The study of the existing solutions for improving the efficiency of the $6 / 10 \mathrm{kV}$ distribution power networks of Horodok DPN revealed that, considering the configuration, power lines length and load, the network changing over to a higher voltage can be regarded as feasible.

2. The analysis of the maximum modes of the functioning $10 / 6 \mathrm{kV}$ PN of Horodok DPN shows that some of the long PL have exhausted its transmission capacity. At that, on the buses of its TS the required voltage level is not ensured. The active power losses in $6 \mathrm{kV} \mathrm{PN}$ are twice as large as those in $10 \mathrm{kV}$ network, and the total losses amount to 3.7993 MW.

3. The outcomes of the study demonstrate that the changeover of some $6 \mathrm{kV}$ PN to $10 \mathrm{kV}$ improves the voltage level on the TS buses of this PN and reduces the technical losses of the active power by $56.52 \%$. However, the loading of the lines and the voltage level on $10 \mathrm{kV}$ PN TS buses remains the same as in the functioning PN's mode. In this case, during the modes with the predicted load these indicators become even worse. The changeover of 10/6 kV PN to $20 \mathrm{kV}$, even for the predicted load, will ensure high performance indices of the PN operation. The voltage losses in PL will be below 3\%, PN TS buses will be provided with the necessary voltage level and the technical losses of the active power will not exceed $3 \%$. The $20 \mathrm{kV}$ power network will have a substantial transmission capacity reserve. 


\title{
References
}

[1] A. Aguila, J. Wilson. Technical and economic assessment of the implementation of measures for reducing energy losses in distribution systems. IOP Conf. Series: Earth and Environmental Science, 73 (2017) 012018. https://doi.org/10.1088/1755-1315/73/1/012018

[2] K. R. Devabalaji, A. M. Imran, T. Yuvaraj, K. Ravi. Power loss minimization in radial distribution system. Energy Procedia, no. 79, pp. 917-923, 2015. https://doi.org/10.1016/j.egypro.2015.11.587

[3] Dikhtiaruk, I.V. The effect of $6-10 \mathrm{kV}$ power networks sectionalisation with automatic breakers on the integral reliability indicators. Electrical Engineering and Industrial Electronics. Technological Audit and Production Reserves. No. 2/1 (28), 2016 pp.35-39. https://doi.org/10.15587/2312-8372.2016.66889 (in Ukrainian)

[4] Rao, R.S., Ravindra, K., Satish, K. and Narasimham, S.V.L. Power loss minimization in distribution system using network reconfiguration in the presence of distributed generation. IEEE Transactions on Power Systems, 28 (1), pp. 317-325, 2013. https://doi.org/10.1109/TPWRS.2012.2197227

[5] R.Gholami, M.Shahabi, M.-R.Haghifam. An efficient optimal capacitor allocation in DG embedded distribution networks with islanding operation capability of micro-grid using a new genetic based algorithm. International Journal of Electrical Power \& Energy Systems, Volume 71, October 2015, Pages 335-343 https://doi.org/10.1016/j.ijepes.2015.03.005

[6] S. Kalambe and G. Agnihotri, Loss minimization techniques used in distribution network: bibliographical survey, Renew. Sustain. Energy Rev., vol. 29, pp. 184-200, Jan. 2014. https://doi.org/10.1016/j.rser.2013.08.075

[7] S. Rao Gampa, D. Das. Multi-Objective Approach for Reconfiguration of Distribution Systems with Distributed Generations. Electric Power Components and Systems, Volume 45, 2017, Issue 15, Pages 1678-1690. https://doi.org/10.1080/15325008.2017.1378944

[8] A. Rajendran, K. Narayanan Optimal Installation of Different DG Types in Radial Distribution System Considering Load Growth Electric Power Components and Systems, Volume 45, 2017, Issue 7, Pages 739-751. https://doi.org/10.1080/15325008.2017.1309721

[9] Singh, A.K. and Parida, S.K., Selection of load buses for DG placement based on loss reduction and voltage improvement sensitivity. In Proc. International Conference on Power Engineering, Energy and Electrical Drives, pp. 1-6, 2011. https://doi.org/10.1109/PowerEng.2011.6036559

[10] Borscevskis O. 20kV Voltage Adaptation Problems in Urban Electrical Networks [E-resource]. URL: http://egdk.ttu.ee (date accessed 12/10/2017).

[11] D.S. Astashev, R.Sh. Bedretdynov, D.A. Kisel, E.N. Sosnina. $20 \mathrm{kV}$ voltage applications in the Russian distribution power networks. Herald NGIEI. 2015, No. 4, pp. 6 - 9. (in Russian)

[12] Kulyk, V.V. Feasibility study of power network reconstruction with the voltage changeover from $10 \mathrm{kV}$ to $20 \mathrm{kV}$ (the case of Pivdenny DPN, Odesaoblenergo OJSC. / V.V. Kulyk, V.O.Komar, O.B.Burykin // Electrical Networks and Systems. No 4-5. - pp.81-86. (in Ukrainian)

[13] Software package Analysis of Power Networks Operation Modes (APNOM) («APEM»): Copyright to a work No. 13579 Ukraine / O.V. Danyliuk, Yu.V. Opotiak, S.V. Diachenko, A.B. Kozovyi. Date registered: 04/07/2005. (in Ukrainian)

[14] Requirements to designing the power transmission lines of 6-35 kV with coated wires. SOU-N EE 40.1-21677681-83:2013. Kyiv. The Ministry of Energy and Coal Mining of Ukraine. 2013. (in Ukrainian)

\section{Підвищення ефективності розподільних електричних мереж 6-10 кВ}

\author{
Зіновій Бахор, Андрій Козовий, Георгій Лисяк, Андрій Яцейко \\ Національний університет «Львівська політехніка», вул. С. Бандери, 12, м. Львів, 79013, Украӥна
}

\section{Анотація}

Об'єктом дослідження $є$ шляхи підвищення ефективності функціонування розподільних електричних мереж напругою 6 та 10 кВ на прикладі Городоцького РЕМ ПрАТ «Львівобленерго» (Україна). Основними недоліками цих електричних мереж $є$ незадовільний технічний стан силового електроустаткування та значна протяжність і недостатня пропускна здатність існуючих ліній електропередачі напругою 6 та 10 кВ. В ході дослідження використовувалися багатофакторна модель, що дозволила врахувати тенденції електроспоживання в регіоні, темпи зростання промисловості, доходів населення і запровадження заходів 3 енергоефективності. А також комп'ютерне симулювання усталених режимів можливих варіантів розвитку електричних мереж, у тому числі й переведення їх на напругу 20 кВ. Отримано кількісну характеристику технологічних показників множини характерних режимів, що дозволило виявити порівняльну ефективність переведення електричних мереж на напругу 20 кВ стосовно інших варіантів. Це пов'язано з тим, що таке переведення має ряд особливостей щодо структури та ефективності функціонування розподільних електричних мереж. Зокрема, збільшується пропускна здатність ліній електропередачі та покращуються умови нормалізації показників якості електроенергії для іï споживачів.

Ключові слова: розподільна електрична мережа; усталений режим; рівень напруги; втрати активної потужності; пропускна здатність. 